\title{
Labour market flexibility and inequality: the changing risk patterns of temporary employment in West Germany
}

\author{
Michael Gebel · Johannes Giesecke
}

Accepted: 28 May 2009 / Published online: 16 July 2009

(C) Institut für Arbeitsmarkt- und Berufsforschung 2009

\begin{abstract}
While previous research on temporary employment has shown that certain labour market groups are more likely than others to enter this kind of employment, there has been scant research on the question concerning to what extent these allocation patterns have changed over time. Against the background of pervasive structural and institutional changes which have affected the West German labour market since the beginning of the 1990s, there are reasons to believe that allocation patterns have changed as well. However, on a theoretical level there are different views regarding the quality of these changes. Whereas some scholars argue that social inequality has been exacerbated along the existing lines of social division, others maintain that risks are becoming less and less socially structured. To evaluate this question empirically, we use data from the German Mikrozensus for the period from 1989 to 2005. The analysis reveals first of all that, on the aggregate level, the overall proportion of temporary employment has increased only slightly during that period; secondly, the results show that especially those individuals belonging to groups that already had a weak labour market position have been allocated increasingly to temporary jobs; thirdly, contrary to the thesis of a de-structuration of social inequality, the findings
\end{abstract}

\footnotetext{
M. Gebel (ه)

Universität Mannheim, Mannheimer Zentrum für Europäische Sozialforschung (MZES),

A5,6, 68159 Mannheim, Germany

e-mail: michael.gebel@mzes.uni-mannheim.de

J. Giesecke

Wissenschaftszentrum Berlin für Sozialforschung (WZB),

Bei der Präsidentin,

Reichpietschufer 50, 10785 Berlin, Germany

e-mail: johannes.giesecke@wzb.eu
}

reveal no decline in the overall importance of "classical" determinants of temporary employment relationships.

\section{Arbeitsmarktflexibilisierung und Ungleichheit: Der Wandel der Risikomuster befristeter Beschäftigung in Westdeutschland}

Zusammenfassung Obwohl viele Studien zur befristeten Beschäftigung zeigen können, dass bestimmte Arbeitsmarktgruppen eine erhöhte Wahrscheinlichkeit aufweisen, in befristeten Arbeitsverhältnissen beschäftigt $\mathrm{zu}$ sein, existieren bisher nur sehr wenige Forschungsergebnisse hinsichtlich der Frage, ob und inwieweit sich diese Allokationsmuster über die Zeit verändert haben. Angesichts tiefgreifender struktureller und institutioneller Veränderungen, die sich seit Anfang der 1990er Jahre auf den westdeutschen Arbeitsmarkt auswirken, liegt jedoch die Vermutung nahe, dass die Allokationsmuster befristeter Beschäftigung ebenfalls einem Wandel unterlagen. Auf der theoretischen Ebene existieren allerdings unterschiedliche Einschätzungen bezüglich der Art eines solchen Wandels. Während einige Beobachter erwarten, dass sich Ungleichheiten auf dem Arbeitsmarkt entlang bereits bestehender sozialer Spaltungslinien verstärken, betonen andere, dass Risiken immer weniger sozial, sondern vielmehr individuell strukturiert seien. Um diese Frage empirisch zu überprüfen, nutzen wir Daten des Mikrozensus für die Jahre 1989 bis 2005. Die Analysen zeigen dabei erstens, dass der Anteil befristeter Beschäftigungsverhältnisse über diesen Zeitraum insgesamt nur leicht angestiegen ist. Zweitens wird deutlich, dass insbesondere solche Gruppen zunehmend in befristeten Arbeitsverhältnissen zu finden sind, die ohnehin eine relativ schwache Position am Arbeitsmarkt aufweisen. Drittens lassen die Ergebnisse erkennen, dass sich die Bedeutung 
„klassischer“ Determinanten befristeter Beschäftigungsverhältnisse entgegen der These einer Entstrukturierung sozialer Ungleichheit nicht verringert hat.

\section{Introduction}

Over the last two decades the West German labour market has gone through a deep crisis and has undergone severe transformation. ${ }^{1}$ This profound restructuring process was inter alia accompanied by an increase in the proportion of so-called "flexible" or "non-standard" employment as one form of labour market flexibilisation (Esping-Andersen and Regini 2000). In this paper we focus on a very prominent form of external flexibility, namely temporary employment. Temporary jobs are characterised by contracts of limited duration that end automatically upon expiry. Through temporary jobs employers are given the chance to lower their labour input adjustment costs, since these contracts reduce the costs of firing an employee (Bentolila and Bertola 1990; Cahuc and Postel-Vinay 2002; Hagen 2003).

Temporary work has given rise to fierce discussions in the scientific literature and in the public arena, with proponents arguing that temporary contracts provide a "bridge" to the labour market, while opponents see temporary contracts as a "trap". Many recent studies report adverse labour market effects on people with fixed-term contracts, though there is also evidence that in the majority of cases these negative effects level off once employees make the transition to permanent employment (Amuedo-Dorantes 2000; Hagen 2002, 2004, 2005, 2006; Booth et al. 2002; Giesecke and Groß 2003; Kalleberg 2000; Mertens et al. 2007). Given the disadvantages of temporary employment, it is important to understand the processes of allocating individuals to these inferior labour market positions. Moreover, against the background of far-reaching structural and institutional change it becomes even more important to investigate the shifts in the allocation patterns and their consequences for the structure of social inequality.

However, while there are some studies on the determinants of temporary jobs in the German labour market (amongst others: Boockmann and Hagen 2006; Buchholz and Kurz 2005; Giesecke 2006; Giesecke and Groß 2003; Groß 1999; Hagen 2002, 2004; McGinnity et al. 2005; Mertens and McGinnity 2004; Schömann et al. 1998), there is only very limited evidence on how these determinants have changed over time. Moreover, so far there is no study that uses multivariate analyses to investigate systematically whether these allocation patterns have changed over time. ${ }^{2}$

\footnotetext{
${ }^{1}$ In the following, the term "Germany" refers to West Germany.

${ }^{2}$ For example, Schömann et al. (1998) compare the incidence of temporary contracts disaggregated by gender, age and educational level in the $1980 \mathrm{~s}$
}

The present paper contributes to the existing literature in three ways. First, we will answer the question of whether or not the risk of holding a temporary contract changed for certain socioeconomic groups in Germany during the period from 1989 to 2005, which is an improvement compared to earlier studies that are restricted to short time periods or to only one period. Using data from the German Mikrozensus, we are able to draw inferences from a large national sample and, furthermore, we can control for a rich set of individual and structural variables. Secondly, we evaluate whether the nexus of "classical" determinants (e.g. age, education and occupational class) and temporary employment has in general remained unchanged or whether these determinants have become less important or more important in the allocation process. However, if the importance of "classical" dimensions of social inequality changes then residual variation is likely to change as well. Thus, thirdly, in order to account for changing residual variation we compare results from standard logistic regressions with heterogeneous choice models, which allow for an unbiased estimation of parameters in case of non-constant variance in the unobserved part of the model.

The paper is structured as follows: in Sect. 2 we discuss structural and institutional changes that may have influenced the determinants of temporary employment over time; Sect. 3 introduces the data set, variables and the statistical methods used; in Sect. 4, results of the empirical analysis are discussed, and in Sect. 5 we present our conclusion.

\section{Changes in the allocation to temporary employment}

Previous empirical studies have shown that the risk of holding a temporary contract is related to various individual as well as job-related characteristics. As the number of potential determinants of temporary employment is rather large, we want to focus the following discussion on the effects of education, age and occupational class. These characteristics are not only important determinants of temporary jobs but also constitute core elements of social stratification and inequality.

Regarding the effects of these determinants, previous studies have shown that for Germany there is, first of all, a non-linear relationship between a worker's educational level and his/her risk of holding temporary employment. High risks can be determined for low-educated persons without vocational training but also for holders of university degrees (a.o. Giesecke and Groß 2003; Hagen 2004; McGin-

and early 1990s. The analysis for age and educational groups, respectively, is limited to two or four time periods, meaning that no real trend can be detected. Furthermore, their trend analysis is only based on simple bivariate models and thus ignores other potential confounding influences. 
nity et al. 2005; Mertens and McGinnity 2004). Second, there is a well-documented association between a worker's age and the risk of holding a temporary contract, with young people facing the highest risk of holding a temporary contract, while older workers are least likely to be employed on a temporary basis (a.o. Boockmann and Hagen 2006; Buchholz and Kurz 2005; Mertens and McGinnity 2004; Schömann et al. 1998). Third, with respect to the effect of occupational class, empirical evidence shows a U-shaped pattern with higher risks for the higher service class as well as for unskilled workers (e.g. Buchholz and Kurz 2005).

Overall, we expect our empirical analysis to confirm the findings of previous studies on determinants of temporary employment. However, the central question of the present paper is whether or not the allocation mechanisms have changed over time. From a theoretical point of view, there are reasons to believe they have, since there have been various macro-structural and macro-institutional changes which might have affected the individual risk patterns. These changes are discussed in the next two sub-sections.

\subsection{Structural changes}

In the sociological literature, authors like Mills and Blossfeld (2005) argue that globalisation - by which is meant several macrostructural trends - has led to structural uncertainty because increasing dynamics and volatility make predictions less precise. There are two conflicting perspectives regarding the effects of increasing uncertainty on social inequality in the labour market. One assumption, put forward particularly by Beck $(1992,2000)$, relates global uncertainty to an individualisation of social inequalities. It is argued that existing determinants of social stratification like education and occupational class will lose their importance for social inequality as new risks unrelated to these "classical" determinants emerge. These new risks will cross boundaries of educational and occupational class thereby equalizing the distribution of labour market risks. Thus, the association between the risk of holding a temporary contract and educational titles/occupational class positions will weaken. If "classical" dimensions of social inequality lose much of their significance, other factors that might remain unobserved in standard surveys will gain in importance. From a statistical point of view, this should be reflected by a decreasing association of "classical" determinants with labour market outcomes, which would, for example, be manifested in a decreased statistical importance of such models of social inequality. At the same time, residual variance in these models might increase.

In contrast to the assumption of a growing individualisation of inequality, authors like Breen (1997) or Goldthorpe (2002) claim that the increasing uncertainty is shifted through pre-existing social inequalities of power and resources. In this perspective, employers try to shift the risks stemming from market uncertainties to groups that customarily were already in a weak labour market position. Thus, traditional social inequality patterns, such as those based on educational resources and occupational class, are expected to persist or even increase. As these characteristics become more important for social inequality, unobserved factors are likely to become less important for the process of allocation to temporary jobs. In statistical terms, this implies an increasing fit of models using "classical" determinants of social inequality, while residual variance in those models might have decreased.

With respect to flexible employment, Breen (1997) argues that employers try to transfer increased market risks stemming from growing market volatilities to their employees (Breen calls this process a recommodification of risks ${ }^{3}$ ). Instead of developing long-term employment relationships, employers tend to use temporary employment contracts that ensure the option of withdrawing from employment contracts at any time. In this process, employees have to bear almost exclusively the increase in market risks by facing a higher degree of uncertainty regarding future job stability. This creates a "contingent asymmetric commitment" (Breen 1997, p. 477): Employers can retain their workers when they are needed and get rid of them when they are no longer needed. However, even in times of high uncertainty, it is rational for firms not to transform all employment relationships into short-term ones. Employers still have an incentive to build up long-term commitments, especially with highly educated employees and employees in higher-skilled occupations, in order to keep a stable, experienced, and highly qualified core workforce. These long-term commitments to highly qualified persons are important to maintain because it is in general difficult to monitor exactly what such workers are doing whereas the tasks of low-educated and unskilled workers can be closely supervised (Goldthorpe 1995, 2000). Thus, temporary contracts are assumed to be particularly prevalent for jobs with low skill requirements. ${ }^{4}$ Therefore, the risk of ending up with a temporary contract will increase for low-educated workers and lower occupational classes compared to more highly skilled workers. ${ }^{5}$

\footnotetext{
3 "Recommodification" means the opposite of Esping-Anderson's (1990) notion of "decommodification" where, for example, welfare regimes acted to "decommodify" individuals by seeking to make their life chances less dependent on market forces.

${ }^{4}$ This trend is probably strengthened by increased bureaucratisation of economic organisation in modern societies and skill-biased technological change, which increase the relative demand for high-skilled workers (Acemoglu 2002). At the same time, the effect of educational expansion, which potentially counteracts the aforementioned trends, can be assumed to be only moderate, given that educational expansion weakened markedly within our period of observation (Müller and Wolbers 2003).

${ }^{5}$ According to Breen (1997), one can expect certain groups like lower-grade technicians and supervisors of manual workers to be at greater risk because
} 
Mills and Blossfeld (2005) extend Breen's argument (1997) to the dimension of age and expect young people, as labour market outsiders, to be especially affected by increasing uncertainty compared to prime-age workers. Following this argument, the risk for young workers of holding a temporary contract will increase relative to other age groups.

\subsection{Institutional changes}

It is often argued that the effects of structural changes like globalisation or skill-biased technological change are mediated through the national institutional setting. Economists maintain that these changes translate into high levels of low-skilled unemployment in Europe because rigid labour market institutions prevent the necessary wage adjustments (Blanchard and Wolfers 2000; Blau and Kahn 2002). In contrast, DiPrete et al. (2006) develop the sociological perspective that European labour markets have absorbed market uncertainties by allocating an increasingly large proportion of unskilled workers to flexible jobs. ${ }^{6}$ Following DiPrete et al. (2006), this trend has been brought on by the deregulation of temporary work contracts being used as a new tool for redistributing labour adjustment costs. They are able to confirm their hypothesis in the case of France, which has experienced a deregulation of the use of temporary contracts. Since French employers were not able to reduce the relative wages of low-educated workers, they increased the concentration of low-educated workers in temporary jobs with low adjustment costs.

Similar predictions can also be derived for the case of Germany. While permanent contracts are still highly protected, the use of temporary contracts has been progressively facilitated in Germany (OECD 2004). For example, the 1985 Employment Promotion Act and later changes to the law in 1996, 2001, and 2003 gradually extended the possibilities for temporary contracts by easing their application and renewals as well as prolonging their maximum duration (for details, see Appendix). This kind of partial labour market reform might be interpreted as an incentive for employers increasingly to use temporary contracts for employing low-educated workers (Blanchard and Landier 2002; Esping-Andersen and Regini 2000). Thus, these institutional changes can be assumed to affect social inequality in the same way as that predicted by the more structural view of Breen (1997).

of organisational changes that reduce monitoring, e.g. responsibility for profits to ever smaller units or performance targets. However, we cannot differentiate these categories in our data. See Sect. 3 for details.

${ }^{6}$ In contrast, in the US, uncertainties have been compensated by rising skillbased inequality of wages.
Unions are another labour market institution that might shape the distribution of the individual risk of holding a temporary contract. According to insider-outsider theory, unions represent the collective interests of labour market insiders (Lindbeck and Snower 2002). In contrast, labour market outsiders, such as young people, are less represented in the negotiations of the social partners. Therefore, one can conclude that the stronger the representation of insiders' interests through unions, the lower the chances that outsiders (such as young people) will obtain permanent contracts. Since the power of unions has weakened over time in Germany (Ebbinghaus and Visser 2000), one can expect, ceteris paribus, that young workers will face a decreasing risk of temporary employment. Noteworthy is that the presumed effect of a weakening in union power counteracts the effect of an increase in temporary employment among youths as expected by Mills and Blossfeld (2005).

In sum, given structural and institutional change, there are theoretical arguments that predict a weakening of the explanatory power of existing patterns of social inequality, while others predict a strengthening of social inequality along existing lines of social division. Unfortunately, the research design of the present article does not allow us to fully disentangle the different macro-level influences. However, given the data, it is at least possible to analyse the joint effects of these changes on individual determinants of temporary employment.

\section{Research design}

\subsection{Data}

For the empirical analysis we use data from the German Labour Force Survey (Mikrozensus), covering the period from 1989 to 2005. This database provides standardised, cross-sectional information on individuals regarding labour force participation, employment characteristics, gender, age, education, occupational status and employment history, as well as other information. The sample size of the scientific use file corresponds to a random sample of 0.7 percent of the population residing in Germany, containing more than 500,000 observations for a given year. Compared to other micro datasets like the German Socio-Economic Panel, the Mikrozensus thus has the advantage of a large number of highly reliable observations. We restrict the sample to employees aged 16-65 who no longer participate in education, i.e. we exclude students and apprentices. The analysis is limited to the period 1989 to 2005, as the central information on contract status is missing prior to 1989. Unfortunately, we cannot use the Mikrozensus waves from 1990, 1992 and 1994, because they are not available for research. Since important information on job characteristics (such as 
firm size or occupational class) is not available in the data before 1996, our analyses are limited to the period 1996 to 2005 whenever job characteristics are investigated. ${ }^{7}$ Furthermore, we decided to restrict the analyses to the West German labour market. Given the radical transformation process of the East German labour market since 1990, a separate analysis would be necessary, which - interesting as it may be would certainly go far beyond the scope of our paper. ${ }^{8}$

\subsection{Variables}

The central variable defining the type of employment contract is a binary indicator, coded 1 for temporary contracts and 0 in the case of a permanent contract. Temporary employment is characterised by the agreement between employer and employee on objective conditions under which a job ends, such as a specific date, the completion of a task or the return of another employee who has been temporarily replaced. In particular, this applies to fixed-term contracts, workers with a contract for a specific task, occasional, casual or seasonal workers, as well as to some temporary agency workers.

The set of explanatory variables reflecting the determinants of the type of an employment contract contain individual and structural characteristics. As standard individual variables we include gender, nationality, age and education. Gender and nationality are dummy-coded whereas age is grouped in ten-year intervals (16-25, 26-35, 36-45, 46-55, and 56-65 years). To control for differences in educational attainment, we use information on the successful completion of different general and vocational educational levels which make it possible to define educational degrees according to the CASMIN classifications (Lechert et al. 2006). CASMIN has the advantage of combining information on the highest school degree and the highest vocational degree. This is especially relevant for the highly standardised and stratified German educational system with its high degree of vocational specificity (Müller and Shavit 1998). The CASMIN categories have been summarised into six categories: elementary education (CASMIN 1a, 1b), elementary education with vocational

\footnotetext{
${ }^{7}$ Moreover, until 2005, standard occupational classifications (as for example ISCO) that are needed to code a person's occupational class are only available for the 45 percent subsample of the Mikrozensus. Thus, the sample size is reduced by more than half whenever this information is used in a statistical model. In order to have similar sample sizes, we draw a 45 percent subsample of the 2005 wave if we estimate models that include occupational information. Actual sample sizes are about 60,000 cases per year.

${ }^{8}$ The Mikrozensus does not allow one to identify those persons who are registered in job-creation measures (the so-called "Arbeitsbeschaffungsmaßnahmen"), which are temporary by definition. While these specific employment forms are important for the East German labour market, they are rather marginal for West Germany (Rudolph 2000).
}

training (CASMIN 1c), intermediate/higher secondary education without vocational training (CASMIN 2b, 2cgen), intermediate/higher secondary education with vocational training (CASMIN 2a, 2cvoc), higher technical college (CASMIN 3a), and university education (CASMIN 3b). Recent labour market history is approximated by the activity status one year prior to the survey. ${ }^{9}$ This variable differentiates between employment, unemployment, inactivity, and participation in education.

We also control for structural influences in the form of firm size and industry sector of employer. Firm size is divided into three groups: small firms (1-10 employees), medium-sized firms (11-50 employees) and large firms (more than 50 employees). Industry sector is measured according to nine aggregated NACE classifications (agriculture, manufacturing, construction, trade, hotels/restaurants, transport/communication, finance/real estate/renting, public administration/education/health, other services). Information on employment status in the public service is combined with the NACE classification as an additional sector category. All persons working in the public sector are coded into this additional category which is independent of their NACE classification. Occupational class differences are captured by using an aggregated version of Erikson and Goldthorpe's (1992) class scheme. The schema differentiates between higher service (EGP I), lower service (EGP II), routine clerical (EGP IIIa), routine service/sales (EGP IIIb), skilled manual (EGP VI), and semi-/unskilled workers and agricultural workers (EGP VII). We derive EGP classes from ISCO-88 coded occupational titles following the procedure of Ganzeboom and Treiman (2003). However, we cannot fully implement the transformation due to data limitations of the Mikrozensus. For example, the class of manual supervisors (EGP V) is missing because information about supervisory status is lacking in the Mikrozensus. Self-employed persons are excluded by our sample selection definition.

\subsection{Statistical methods}

In order to analyse changes in the inequality structure of temporary employment we estimated binomial logistic regressions where the binary indicator of having a temporary contract is regressed on a set of explanatory variables as outlined above. These regressions are estimated for each year separately, thereby allowing us to compare logit regression coefficients over time. ${ }^{10}$ A simple strategy to

\footnotetext{
${ }^{9}$ Unfortunately, we do not have a measure of labour market experience in our data. Thus, a clear distinction between age and experience effects is not possible.

${ }^{10}$ Although, we control for a rich set of observed variables and allow for flexible interactions with time by estimating the logistic regression sepa-
} 
investigate overall changes in the determinants of temporary employment over time is to compare measures of the model's goodness of fit. Whereas in linear regressions the coefficient of determination $R^{2}$ is the standard concept, there is a huge variety of measures in the case of logistic regressions (Long 1997; Long and Freese 2006). Therefore, we choose to compare two distinct measures of the model's goodness of fit: McFadden's $R^{2}$ and Akaike's Information Criterion (AIC). ${ }^{11}$

Finally, we implement two models that test for changes in the effect of age, education, and occupational class assuming a linear time trend. These models are estimated using the pooled Mikrozensus data. While one of these models is a standard logit model, the other is a heterogeneous choice model that takes into account changes in residual variance over time. Besides explicitly modelling a time-dependent residual variance, this model makes it possible to counter potential bias stemming from heteroscedasticity (i.e. varying residual variance) in standard logit models. Whereas in the context of ordinary least squares regression heteroscedasticity does not bias the parameter estimates, this causes more problems in logit regressions: In case of varying variances of the error term, not only are the standard errors incorrect, but the parameters are also biased and inconsistent. In order to deal with these problems, heterogeneous choice models for the logit model have been developed (Alvarez and Brehm 1995; Keele and Park 2006). Deriving the binary choice model in a latent variable framework (e.g. Wooldridge 2002), we have

$$
\begin{aligned}
\operatorname{Pr}\left(Y_{i}=1\right) & =\operatorname{Pr}\left(Y_{i}^{*}>0\right) \\
& =\operatorname{Pr}\left(X_{i} \beta+\varepsilon_{i}>0\right)=\operatorname{Pr}\left(\varepsilon_{i} \leq X_{i} \beta\right) .
\end{aligned}
$$

In the logit case the error term $\varepsilon_{i}$ is assumed to follow a logistic distribution $\Lambda$. To estimate the standard logit model, it must be assumed that the error term is homoscedastic or constant such that

$$
\operatorname{Pr}\left(Y_{i}=1\right)=\operatorname{Pr}\left(\frac{\varepsilon_{i}}{\sigma} \leq \frac{X_{i} \beta}{\sigma}\right)=\Lambda\left(\frac{X_{i} \beta}{\sigma}\right) .
$$

The regression parameters will estimate the true coefficients only up to the scale $(\hat{\beta}=\beta / \sigma)$. Thus, if the assumption of a constant error variance is violated, for example because the error variance changes over time, then the parameter estimates will be biased. Accordingly, comparing logit coefficients across groups or time is invalid and misleading if residual variance varies (Allison 1999). For the analyses of this paper the results from standard logit models might suggest that estimated logit coefficients have changed,

rately for each year, our results should not be interpreted as true causal effects.

${ }^{11}$ We do not present results for other Pseudo- $R^{2}$ or information criteria because they do not alter the results in a significant way. although the true coefficients remained stable but the residual variance changed over time. Likewise, it is possible that estimated coefficients remain stable over time although the true values have changed and this has been countervailed by changing residual variation. In contrast to standard logit models, heterogeneous choice models assume that the error variance varies systematically (for an overview, see Keele and Park 2006; Williams 2007). The variance component in heterogeneous choice models is modelled parametrically as

$$
\operatorname{var}\left(\varepsilon_{i}\right)=\sigma_{i}^{2}=\left[\exp \left(Z_{i} \gamma\right)\right]^{2},
$$

where $Z_{i}$ are variables that explain the changing variance. The $Z_{i}$ 's and $X_{i}$ 's need not include any of the same variables, although they can. Then, the probability of observing outcome $Y=1$ is modelled as

$$
\operatorname{Pr}\left(Y_{i}=1\right)=\Lambda\left(\frac{X_{i} \beta}{\exp \left(Z_{i} \gamma\right)}\right)
$$

Maximizing the log likelihood of the heteroscedastic logit model will produce unbiased and consistent estimates of the true coefficients $\beta$ if the residual variance Eq. 3 is well specified. ${ }^{12}$

\section{Empirical results}

The empirical section of the paper is divided into two parts. The first subsection provides a brief overview of the development of temporary employment in the West German labour market over the last decades. In addition, proportions of temporary employment for different age groups, educational levels and occupational classes are presented in order to take a preliminary look at the distribution of temporary jobs across these social groups. This very descriptive section complements the second part which discusses the results of models that simultaneously relate the risk of holding a temporary contract to characteristics of the worker as well as to features of the job itself. These models are intended to provide statistically robust tests on the changing impact of "classical" determinants of temporary employment.

\subsection{Some stylised facts on temporary employment} in West Germany

This first descriptive section provides some stylised facts on the development and structure of temporary employment in West Germany. Table 1 presents the overall proportion of temporary employment for selected years in the period 1989-2005. Furthermore, group-specific proportions for

\footnotetext{
${ }^{12}$ For a detailed discussion of the model's statistical properties see Keele
} and Park (2006). 
Table 1 Risk of temporary employment by selected demographic and educational groups (in percentages)

\begin{tabular}{|c|c|c|c|c|c|}
\hline & 1989 & 1993 & 1997 & 2001 & 2005 \\
\hline All & 5.6 & 5.2 & 5.4 & 6.2 & 7.3 \\
\hline \multicolumn{6}{|l|}{ Age } \\
\hline $16-25$ years & 11.4 & 13.8 & 14.7 & 18.1 & 24.7 \\
\hline $26-35$ years & 7.0 & 5.9 & 7.1 & 7.9 & 10.6 \\
\hline $36-45$ years & 3.4 & 3.3 & 3.9 & 4.7 & 5.5 \\
\hline $46-55$ years & 2.8 & 2.3 & 2.3 & 3.1 & 3.3 \\
\hline $56-65$ years & 2.9 & 2.4 & 2.5 & 2.8 & 3.2 \\
\hline \multicolumn{6}{|l|}{ Education } \\
\hline Elementary & 5.7 & 4.8 & 5.7 & 7.2 & 8.5 \\
\hline Elementary + voc. & 3.8 & 3.3 & 3.4 & 4.1 & 5.1 \\
\hline Intermediate/full secondary & 15.4 & 16.7 & 12.0 & 12.4 & 13.7 \\
\hline Intermediate/full secondary + voc. & 5.5 & 4.8 & 4.7 & 5.2 & 6.6 \\
\hline Higher technical college & 5.3 & 3.7 & 5.4 & 5.3 & 6.3 \\
\hline University & 12.3 & 11.0 & 12.4 & 12.4 & 12.0 \\
\hline \multicolumn{6}{|l|}{ Occupational Class ${ }^{\mathrm{a}}$} \\
\hline Higher service & - & - & 9.4 & 8.9 & 9.6 \\
\hline Lower service & - & - & 4.6 & 5.2 & 5.7 \\
\hline Routine clerical & - & - & 4.7 & 5.5 & 6.4 \\
\hline Routine service and sales & - & - & 4.6 & 5.8 & 7.1 \\
\hline Skilled manuals & - & - & 3.5 & 4.1 & 5.8 \\
\hline Semi- and unskilled manuals & - & - & 5.4 & 6.4 & 7.7 \\
\hline
\end{tabular}

Source: Authors' own calculations based on Mikrozensus 1989-2005 data.

${ }^{a}$ Information on occupational class was not available in the data before 1996 (see Sect. 3.1) certain demographical and educational groups as well as occupational classes are reported. Because of the crosssectional design of the Mikrozensus, the percentages refer to the stock of temporary workers recorded on a reference day, rather than the total number of employment contracts in force during a particular year.

Table 1 shows that the proportion of temporary workers remained fairly constant during the 1990s, varying in the 5 to 6 per cent interval. After 1989, there was a slight decrease to 5.2 percent in 1993 when the post-unification boom ended, increasing again to 6.2 percent in 2001. In the new millennium, the slight upward trend continued, reaching a maximum of 7.3 percent in 2005. Overall, these figures suggest that the changes in the regulation of the use of temporary contracts (see Appendix) did not lead to a massive increase in the proportions of this type of employment. Obviously, employing staff on a temporary basis is not the only means by which German employers achieve flexibility. However, looking at the group-specific proportions of temporary jobs, it becomes clear that labour market flexibilisation did not affect the work force in a universal way, but rather mainly affected those labour market groups whose positioning was already weak.

With respect to the risk differentials between age groups, the findings displayed in Table 1 confirm the results of pre- vious research: The risk of holding a temporary contract is highest for young workers and lowest for older employees. Comparing these differentials over time reveals a strong increase in age-related inequality in the risk of being temporarily employed. As can be seen from Table 1, for persons aged between 16 and 25 the risk of holding a temporary contract more than doubled during the observation period, reaching a comparatively high level of 24.7 percent in $2005 .{ }^{13}$ Given the relatively constant overall proportion, this implies that the relative risk has increased substantially for young people.

There is also a significant variation in the proportions of temporary employment across educational groups. Interestingly, there are only small differences between the primary, secondary and tertiary educational level. However, at all educational levels, holders of vocational qualification certificates are less likely to find themselves in temporary employment. For example, the level of temporary employment for persons with intermediate or full secondary education without vocational qualification is about three times higher than

\footnotetext{
${ }^{13}$ It should be noted that we excluded apprentices from our analysis. Thus, the proportion of temporary jobs does not simply reflect the higher proportion of apprentices holding temporary contracts in the age group 16-25 years.
} 
it is for those with a vocational qualification. ${ }^{14}$ At the tertiary level, the proportion of university degree holders with temporary jobs is twice as high as the corresponding proportion of graduates from higher technical colleges, which are more vocationally oriented. The positive vocational effect is also found on the primary level, but it is less pronounced. These findings are in line with those from previous research. Regarding time trends, we find that - starting in the mid 1990s - at the primary level persons with vocational or general education faced an increasing risk of holding a temporary contract. At the same time, the corresponding risk for persons with a general education at secondary and tertiary level decreased slightly. While this implies a convergence in education-related temporary employment risks, it is the labour market position of those with low-level qualifications that has worsened during the last ten years.

Level differences are less pronounced along the occupational class dimension. It turns out that occupational positions belonging to the higher service class are on average more likely than other positions to be related to temporary jobs. Detailed scrutiny of the occupational level (not shown) reveals that this higher incidence of temporary jobs is especially due to the incidence of professionals within the higher service class. Furthermore, besides positions in the higher service class, those in the semi- and unskilled manual class are more likely than others to be tied to a temporary contract. This U-shaped risk pattern, which matches the findings of previous research (a.o. Buchholz and Kurz 2005), is somewhat at odds with the idea that employment contracts are different for occupations of the service class and those of the manual classes (Goldthorpe 2000). The discrepancy between the higher service class and other occupational classes was slightly less in evidence during the observation period because all other classes registered an increasing risk of holding a temporary contract. However, the increase is particularly pronounced for the lower occupational classes, which indicates growing labour market risks for workers in those positions.

For the sake of brevity, we only present results from models that were estimated for both men and women simultaneously. This is justified by the fact that taking into account gender-specific risk patterns by estimating separate models for men and women does not substantially alter our results, particularly with respect to the time trend of age, education and occupational class. ${ }^{15}$

\footnotetext{
${ }^{14}$ It is important to note that people with secondary education without vocational or tertiary education represent a very small and selective group, which mainly consists of drop-outs from tertiary education.

${ }^{15}$ However, there are some differences between men and women with respect to the level of the effects of age, education and occupational class. First, the age-related risk of holding a fixed-term contract is more pronounced for young men than for young women. Second, the effect of vocational training turns out to be a little stronger for men. Third, the class
}

In sum, we are able to confirm the social risk patterns of temporary employment found in the existing literature: Young persons, holders of more generally oriented educational certificates, and employees from the higher service/the semi- and unskilled manual class face higher risks of holding a temporary contract compared to other social groups. Regarding descriptive time trends, we find that the risk of holding a temporary contract seems to have increased across the age dimension. This is in line with the prediction of Mills and Blossfeld (2005) that young people, as labour market outsiders, are especially affected by increasing market uncertainty. We can also confirm the prediction of DiPrete et al. (2006) who argue that European labour markets have absorbed market uncertainties by allocating an increasingly large proportion of unskilled workers to flexible jobs. As the risk of holding a temporary contract increased for workers with lower education and from lower social classes, these groups lost much of their relative advantage compared to workers holding a university degree and those from the higher service class, respectively, who used to face the highest risks of holding a temporary job. Overall, the results of the descriptive analysis suggest that social inequality is increasing along existing lines of social division. Though this most clearly holds for the age division of temporary employment risks, inequality patterns across educational groups and occupational classes have changed in such a way that the risks have increased for weak labour market groups.

\subsection{Changing risk patterns of temporary employment?}

In the second part of our empirical analysis, we investigate the determinants of temporary employment at the individual level by estimating logit models separately for each year. ${ }^{16}$ In addition to individual characteristics like age, gender, nationality, and education, the models contain information about structural features such as firm size, industry sector and occupational class, as well as activity for the previous year. Since the latter variables are only available from 1996 onwards, the observational period has been shortened to ten years. The contribution of these models is twofold. First, they investigate the impact of structural characteristics on the risk of holding a temporary contract, which is estimated net of the effects of job holders' individual characteristics. Thus, in contrast to the descriptive analysis, it is possible to

differentials described above are somewhat more pronounced for women than for men. The results of the gender-separated analyses are available on request from the authors.

${ }^{16}$ Logit coefficients are derived from standard logistic regression that rest on the assumption of a time-constant residual variation (see Sect. 3.3 for more details). Since the estimated coefficients do not substantially differ from those obtained from heteroscedastic choice models, we present results from the standard logit models only. 


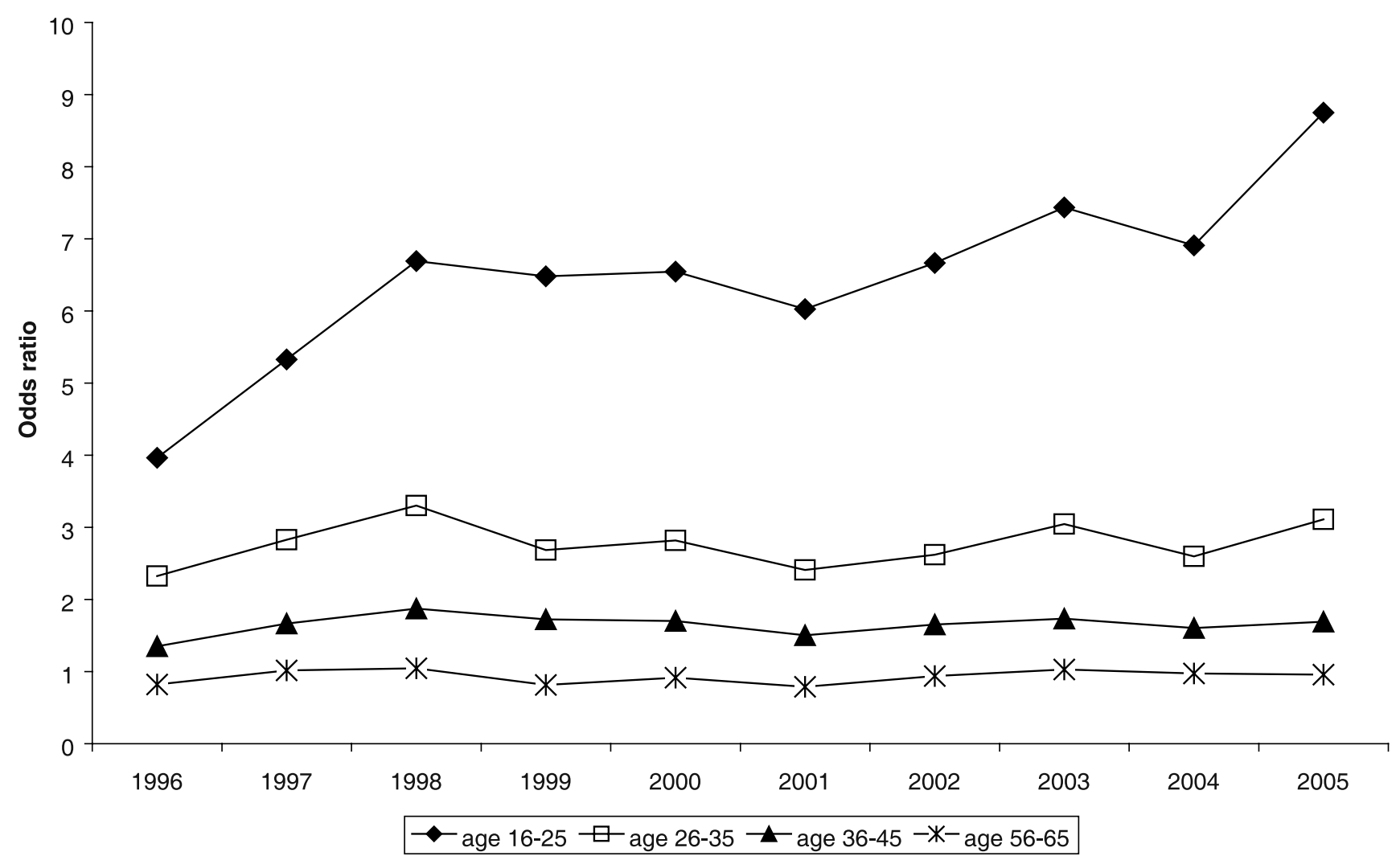

Fig. 1 Odds ratios for age groups, 1996-2005, Reference group: 46-55-year-old employees (Source: Authors' own calculations based on Mikrozensus 1996-2005 data)

evaluate that part of the association of occupational class and temporary employment that is not due to the specific composition of the occupational classes (e.g. inter-class differences in workers' average age or educational level) but to the specific structural characteristics of these positions. Secondly, by looking at measures of model fit, it can be investigated whether or not the importance of structural factors in the process of allocation to temporary jobs has changed over time.

In line with our descriptive findings, we can confirm the general pattern that the older the person the lower his/her risk of holding a temporary contract, even after controlling for a set of demographic and job-related characteristics (cf. Fig. 1). Especially the youngest age group has a significantly higher risk of holding a temporary contract compared to all other age groups. Thus, young workers lacking work experience, seniority and networks are more likely to find themselves in temporary jobs than in permanent ones. ${ }^{17}$ With respect to the changes in the

\footnotetext{
${ }^{17}$ With respect to the effect of age at least two aspects need to be considered. As shown by Giesecke and Groß (2003) older people are more likely to be found in permanent jobs than young people because specific human capital requires permanent employment, and seniority rules keep people in
}

impact of age on the probability of being in temporary employment, the results clearly indicate that the youngest age cohort is confronted with an increasing risk of ending up with a temporary contract. While in 1996 their risk of holding a temporary contract was about four times higher than that faced by persons aged 46 to 55 , this ratio had risen to about nine in 2005. At the same time, no other age group shows an increased risk of holding a temporary contract. This result confirms the predictions of Mills and Blossfeld (2005). Furthermore, the idea that a weakening of trade union power has decreased the insider-outsider cleavages to a considerable extent is not supported by the data.

Figure 2 displays the odds ratios for different educational groups. ${ }^{18}$ When compared to the reference group of workers holding university degrees, all other educational groups face a lower risk of holding a temporary contract. This is espe-

these jobs. However, when changing their jobs, both young and old people face the highest risk of getting only a temporary job. See also the results of Boockmann and Hagen (2006).

${ }^{18}$ The effects of education are estimated "net of" social class. However, sensitivity analyses show that the effects do not change significantly if social class is excluded from the model. 


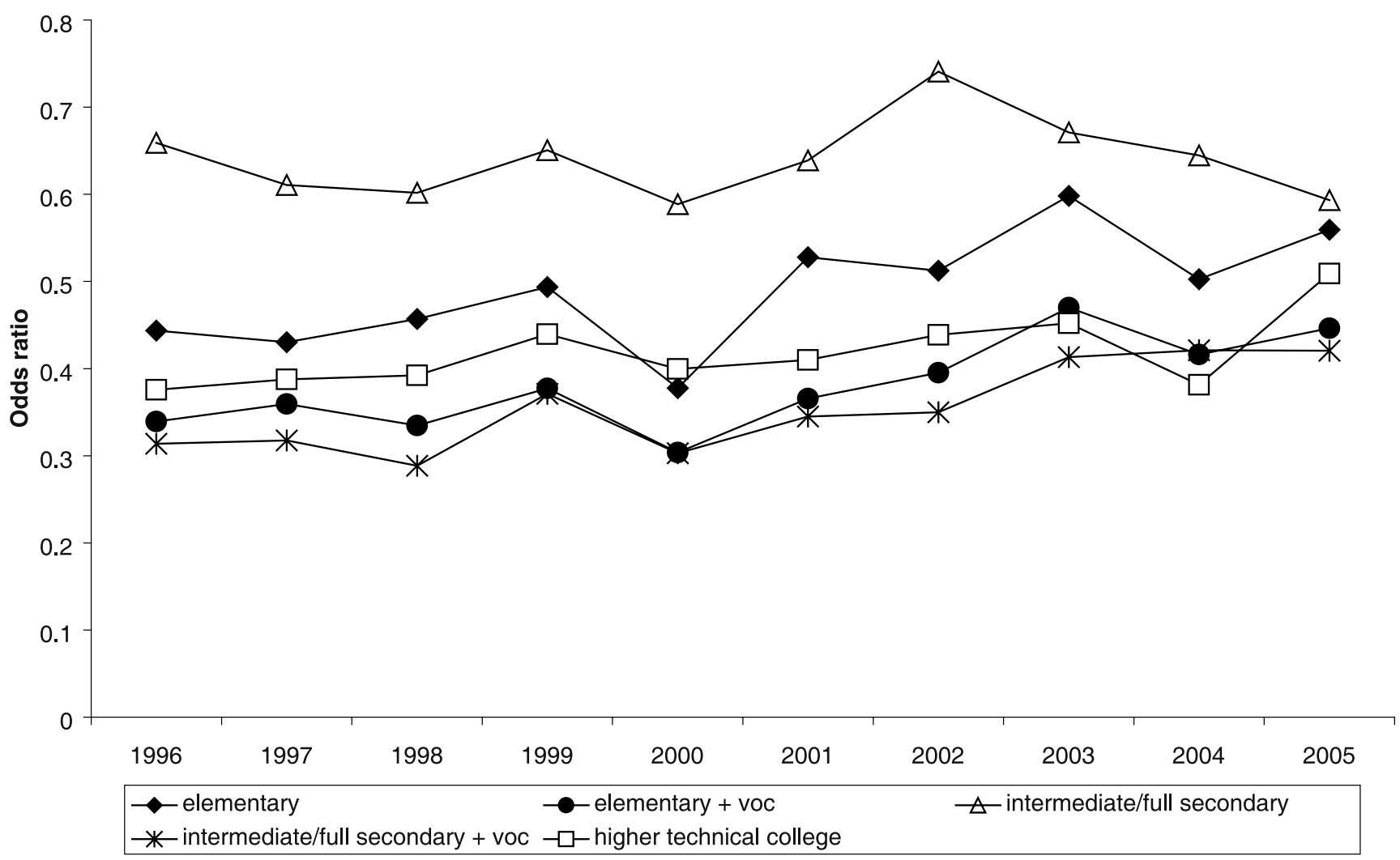

Fig. 2 Odds ratios for educational groups, 1996-2005, Reference group: university education (Source: Authors' own calculations based on Mikrozensus 1996-2005 data)

cially the case for people with vocational training and higher technical college qualifications. For example, in 2005, for persons with elementary education and vocational training the risk of holding a temporary instead of a permanent contract is about 40 per cent of that faced by persons with university education. The results indicate that - after controlling for basic demographic characteristics - the level of education does not seem to matter much for the risk of holding a temporary job. Rather it is the completion of vocational training that matters, which is in line with our descriptive findings and the results of previous studies (a.o. Giesecke 2006; Giesecke and Groß 2003).

Regarding the trend of odds ratios over time, one can detect a convergence in education-related temporary employment risks. Especially those with elementary education (with and without vocational training) and those with intermediate/full secondary education with vocational training faced an increasing risk and lost much of their relative advantage compared to persons with university education. As in the descriptive analysis, the evidence from the multivariate analysis confirms the general prediction of DiPrete et al. (2006) that an increasingly large proportion of low-educated workers are allocated to flexible jobs. Our findings clearly suggest an increasing risk for low-educated workers in Germany, as DiPrete et al. (2006) have found for France. ${ }^{19}$

Figure 3 shows the estimated effects of occupational class on the risk of holding a temporary contract. The results indicate that, compared to the reference group of higher service class positions, occupational positions from all other classes exhibit lower proportions of temporary jobs. This finding is similar to the results of the descriptive analysis. However, in contrast to these results, the multivariate analysis reveals that, net of job holders' individual characteristics, the risk of semi- and unskilled manual workers is not always higher than that of workers from other lower classes. At the same time, positions in the lower service class seem least likely to be linked with temporary contracts. This higher chance of holding a permanent contract corresponds with the theoretical perspective which argues that employers prefer permanent contracts in order to build up long-term employment relationships, so as to maintain a stable, experienced and highly qualified core workforce. The

\footnotetext{
${ }^{19}$ However, in contrast to France, university graduates in Germany face the highest relative risk of holding a temporary contract, so that the increasing risk for low-educated workers translates into a convergence in educationrelated temporary employment risks.
} 


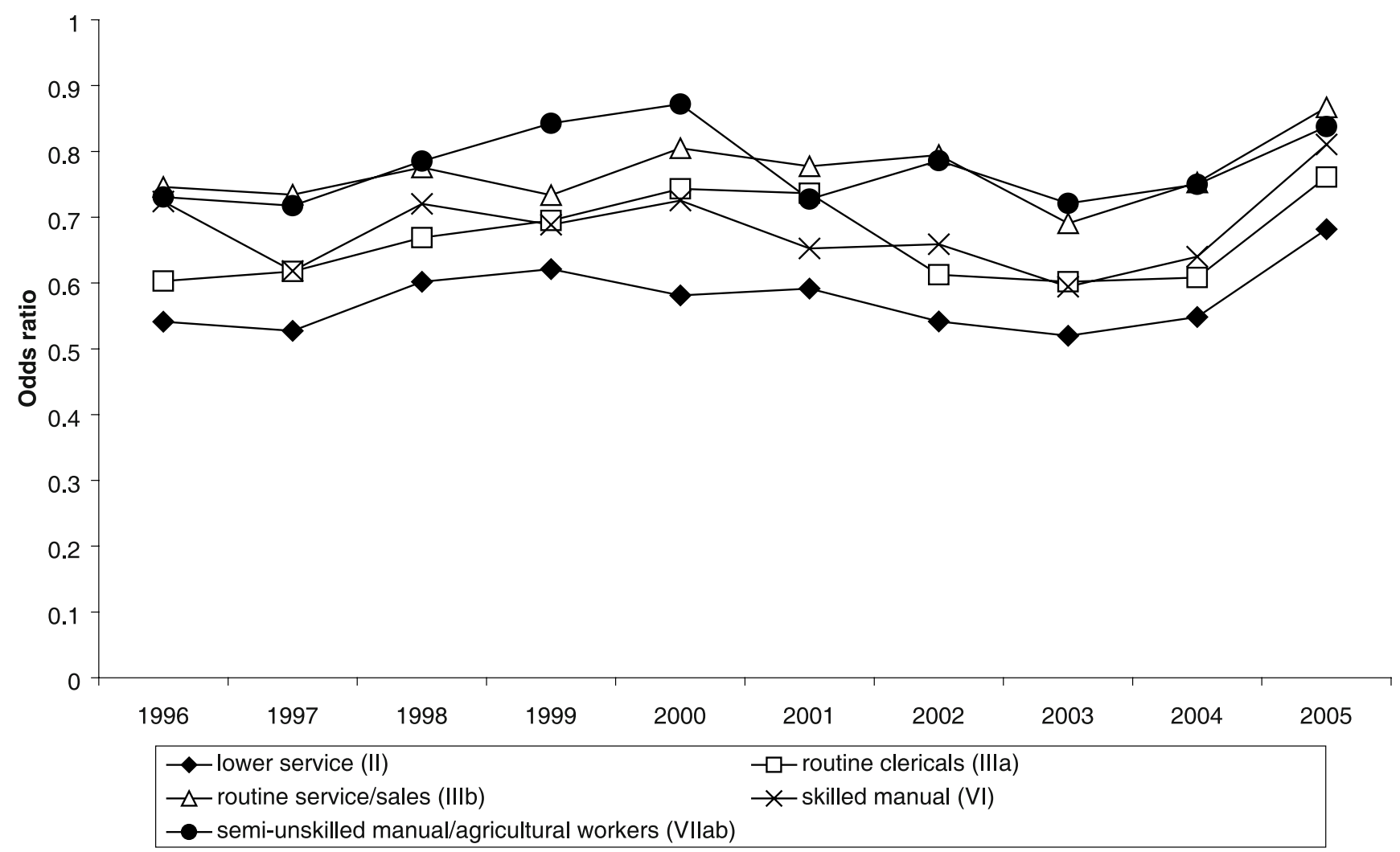

Fig. 3 Odds ratios for EGP classes, 1996-2005, Reference group: Higher service class (EGP I) (Source: Authors' own calculations based on Mikrozensus 1996-2005 data)

relatively high risk characteristic of occupational positions in the higher service class, which is not in line with this argument, can mainly be attributed to the disproportionately high risk of temporary employment faced by professionals, while managerial positions show a risk of being temporary comparable to that of other occupational classes (detailed analysis not shown).

With respect to changes in the effects of occupational class over time, Fig. 3 does not provide evidence in favour of the assumption of an increasing risk faced by lower class positions. Though in the last two years there has been a slight convergence of the risk of holding a temporary contract between classes, for the whole observational period there is hardly any clear-cut time trend in the estimated effects of the occupational classes: Over the ten-year observational period, occupational class-related inequality structures show trendless fluctuations. This implies that for workers from lower occupational classes there has been no increase in the risk of being employed in temporary jobs, despite structural and institutional changes during the period. Thus, these results contradict the predictions of Breen (1997), according to which the lower classes will be increasingly exposed to flexible employment relationships. Comparing these findings with those from the descriptive analysis reveals that the reported increase in the proportion of temporary jobs in lower occupational classes results mainly from the specific composition of these classes (i.e. higher proportions of young and less-educated workers) rather than from shifts in the risk differentials between occupational positions per se.

In a next analytical step, the overall importance of individual and job-related characteristics for the process of allocating people to temporary employment relationships is evaluated. In order to do so, we compare Pseudo- $R^{2}$ (Mc Fadden) and Akaike's Information Criterion (AIC), which are two commonly used measures of the model's goodness of fit. To ensure comparability of each of these measures over time, we repeated the analysis from above but drew a random sample with a size of 50,000 persons for each year. As can be seen from Table 2, there is no clear evidence of a decreasing or an increasing association of the individual characteristics used in the model and the risk of holding a temporary contract. Looking at the Pseudo- $R^{2}$ measure, the association of the individual characteristics and temporary employment seems to have increased slightly between 1989 and 2005. In contrast, the development of AIC suggests a slight decrease in the model fit. Thus, these measures of the model's goodness of fit do not 
Table 2 Importance of individual and job-related characteristics: Pseudo- $R^{2}$ and AIC, 1996-2005

\begin{tabular}{lllllllllll}
\hline & 1996 & 1997 & 1998 & 1999 & 2000 & 2001 & 2002 & 2003 & 2004 & 2005 \\
\hline Pseudo- $R^{2}$ & 0.157 & 0.161 & 0.165 & 0.157 & 0.152 & 0.141 & 0.138 & 0.142 & 0.145 & 0.155 \\
AIC & 15,465 & 16,666 & 17,281 & 18,945 & 18,353 & 18,877 & 18,004 & 18,385 & 18,990 & 21,383
\end{tabular}

Source: Authors' own calculations based on Mikrozensus 1996-2005 data.

Remark: Random samples of size 50,000 drawn for each year to assure comparability of Pseudo- $R^{2}$ and AIC over time. provide clear-cut results regarding changes in the overall importance of individual and job-related characteristics for the process of allocating people to temporary employment relationships.

In the last step of our analysis, we estimated both a heterogeneous choice model and a standard logit model for the full model specification using the pooled data from 1996 to 2005. Estimating these models serves two purposes. First, the heterogeneous choice model allows one to specify and test changes in the residual variation. From a theoretical perspective, the predictions about the way residual variation might have changed over time were not univocal. Empirically, the findings of the last sub-section suggest a slight decrease in the model fit over time, which might indicate an increase in residual variation. In order to test for changes in the residual variance component, we specified a heterogeneous choice model using a general linear time trend, i.e. residual variation is modelled as $\operatorname{var}\left(\varepsilon_{i t}\right)=[\exp (t \gamma)]^{2}$. As discussed in the section on statistical methods (Sect. 3.3), an increase in the residual variation leads to a downward bias of the coefficients estimated in standard logit models and vice versa. Thus, the amount of temporal change in the impact of "classical" determinants on the likelihood of holding a temporary job might be overestimated in such models. Second, by pooling the data, we are able to conveniently test for time trends in the effects of age, education, and occupational class on the risk of holding a temporary contract. Up to this point, the temporal changes in these effects have been discussed without referring to the question of statistical significance of the reported changes. In order to account for a timevarying impact of the observed characteristics on the risk of holding a temporary contract, all explanatory variables in the model are interacted with a linear time trend..$^{20}$ Using this model specification, we are able to provide proper statistical tests on the empirical findings on changing allocation patterns discussed so far. In order to check the robustness of our results, we compare the estimates of a heterogeneous choice model with those of a corresponding standard logit model that ignores the issue of non-constant

\footnotetext{
${ }^{20}$ In addition to these interaction terms, a general linear time trend is incor-
} porated to account for a general increase in the risk of temporary contracts. residual variation. Table 2 reports the estimation results of these models. ${ }^{21}$

Looking at the results displayed in Table 3, there are two points that should be particularly emphasized here. First, with respect to the time trend in the residual variation, which is explicitly modelled in the heterogeneous choice model, it becomes obvious that residual variation has slightly increased over time at a rate of about one percent per year. However, this time trend is far from statistically significant. This insignificance is also reflected in the values of the log likelihood, which show no substantial improvement when comparing the heterogeneous choice model to the standard logit model, which assumes a constant error variance. Thus, the data clearly refute the assumption that the importance of unobserved determinants of the risk of holding a temporary contract has increased over time. In statistical terms, this result implies that the estimates of the standard logit model do not suffer from bias stemming from non-constant residual variation. This is reflected by the fact that, when comparing the two models, most of the estimated coefficients for the variables and their interactions with the time trend are quite similar. The major difference between the two models can be found in the sharply decreased $t$-values of the coefficients capturing time trends. This particularly holds for the estimated time trends of the educational groups, which are estimated with a higher degree of uncertainty in the heterogeneous choice model. Thus, the decrease in $t$-values is mainly due to inflated standard errors in the heterogeneous choice model. Given this difference and the finding of an insignificant time trend in the residual variation, we rely on the results of the standard logit model..$^{22}$

With respect to the time trends in the effects of age, education and occupational class, the results of the model using the pooled data confirm the findings of the previous subsections. As can be seen from Table 3, the risk of holding a temporary job is highest for the youngest age group. This

\footnotetext{
${ }^{21}$ To ease convergence of the complex heteroscedastic choice model, we drew random samples of equal size of 50,000 persons for each year.

${ }^{22}$ It should be stressed here, that it is important to consider heteroscedastic choice models as part of those analyses that compare logit coefficients over time. Only if the heterogeneous choice model shows no significant changes in residual variation, as in our case, is the use of conventional logit analyses justified.
} 
Table 3 Comparison of pooled logit and heterogeneous choice model, full specification 1996-2005

\begin{tabular}{|c|c|c|c|c|}
\hline & \multicolumn{2}{|l|}{ Pooled logit } & \multicolumn{2}{|c|}{ Heterogeneous choice } \\
\hline & Coeff. & $t$-stat & Coeff. & $t$-stat \\
\hline Time trend $t$ & $0.03^{* *}$ & $(2.01)$ & -0.02 & $(-0.32)$ \\
\hline \multicolumn{5}{|l|}{ Age group (Ref. 56-65) } \\
\hline Age $16-25$ & $1.70^{* * *}$ & (27.83) & $1.69^{* * *}$ & $(25.91)$ \\
\hline$t^{*}$ age $16-25$ & $0.05^{* * *}$ & $(4.60)$ & $0.08^{* *}$ & $(2.08)$ \\
\hline Age $26-35$ & $1.09^{* * *}$ & (19.26) & $1.09^{* * *}$ & (18.68) \\
\hline$t^{*}$ age $26-35$ & -0.00 & $(-0.04)$ & 0.02 & $(0.70)$ \\
\hline Age $36-45$ & $0.58^{* * *}$ & $(9.93)$ & $0.57^{* * *}$ & $(9.60)$ \\
\hline$t^{*}$ age $36-45$ & 0.00 & $(0.16)$ & 0.01 & $(0.68)$ \\
\hline Age $46-55$ & $0.13^{* *}$ & $(2.09)$ & $0.13^{* *}$ & $(2.05)$ \\
\hline$t^{*}$ age $46-55$ & -0.01 & $(-1.21)$ & -0.01 & $(-1.10)$ \\
\hline \multicolumn{5}{|l|}{ Education (Ref. university) } \\
\hline Elementary & $-0.85^{* * *}$ & $(-15.88)$ & $-0.86^{* * *}$ & $(-15.51)$ \\
\hline$t^{*}$ elementary & $0.03^{* * *}$ & $(3.03)$ & 0.02 & $(1.46)$ \\
\hline Elementary + voc & $-1.12^{* * *}$ & $(-23.48)$ & $-1.12^{* * *}$ & $(-22.92)$ \\
\hline$t^{*}$ elementary + voc & $0.03^{* * *}$ & $(3.49)$ & 0.02 & $(1.03)$ \\
\hline Intermediate/full secondary & $-0.46^{* * *}$ & $(-8.02)$ & $-0.47^{* * *}$ & $(-7.83)$ \\
\hline$t^{*}$ intermediate/full secondary & 0.00 & $(0.47)$ & -0.00 & $(-0.07)$ \\
\hline Intermediate/full secondary + voc & $-1.22^{* * *}$ & $(-27.82)$ & $-1.22^{* * *}$ & $(-27.13)$ \\
\hline$t^{*}$ intermediate/full secondary + voc & $0.04^{* * *}$ & $(4.89)$ & 0.03 & $(1.47)$ \\
\hline Higher technical college & $-0.96^{* * *}$ & $(-17.26)$ & $-0.96^{* * *}$ & $(-16.86)$ \\
\hline$t^{*}$ higher technical college & $0.02^{*}$ & $(1.72)$ & 0.01 & $(0.38)$ \\
\hline \multicolumn{5}{|c|}{ Occupational class (Ref. higher service (I)) } \\
\hline Lower service (II) & $-0.57^{* * *}$ & $(-13.03)$ & $-0.57^{* * *}$ & $(-12.69)$ \\
\hline$t^{*}$ lower service (II) & 0.00 & $(0.06)$ & -0.01 & $(-0.58)$ \\
\hline Routine clericals (IIIa) & $-0.43^{* * *}$ & $(-8.19)$ & $-0.43^{* * *}$ & $(-7.99)$ \\
\hline$t^{*}$ routine clericals $(\mathrm{IIIa})$ & 0.00 & $(0.26)$ & -0.00 & $(-0.26)$ \\
\hline Routine service/sales (IIIb) & $-0.30^{* * *}$ & $(-5.71)$ & $-0.30^{* * *}$ & $(-5.56)$ \\
\hline$t^{*}$ routine service/sales $(\mathrm{IIIb})$ & 0.01 & $(0.90)$ & 0.01 & $(0.47)$ \\
\hline Skilled manual (VI) & $-0.38^{* * *}$ & $(-6.88)$ & $-0.38^{* * *}$ & $(-6.66)$ \\
\hline$t^{*}$ skilled manual (VI) & -0.00 & $(-0.08)$ & -0.01 & $(-0.52)$ \\
\hline Semi-/unskilled manuals (VII) & $-0.25^{* * *}$ & $(-5.09)$ & $-0.26^{* * *}$ & $(-4.98)$ \\
\hline$t^{*}$ semi-/unskilled manual (VII) & -0.00 & $(-0.16)$ & -0.00 & $(-0.46)$ \\
\hline Constant & $-3.26^{* * *}$ & $(-45.43)$ & $3.26^{* * *}$ & $(44.21)$ \\
\hline \multicolumn{5}{|l|}{ Residual variation $\ln \left(\sigma^{2}\right)$} \\
\hline Time trend $t$ & - & - & 0.01 & $(0.88)$ \\
\hline Log Likelihood & $-102,969.9$ & - & $-102,969.5$ & - \\
\hline $\mathrm{N}$ & 571,017 & - & 571,017 & - \\
\hline
\end{tabular}

Source: ${ }^{*} p<0.10,{ }^{* *} p<0.05,{ }^{* * *} p<0.01$

Authors' own calculations based on Mikrozensus 1996-2005 data.

Remark: Only selected coefficients are reported. In addition to these variables, the full specification contains information on activity status in the previous year, gender, nationality, firm size, sector, and interactions with time for each variable. risk has increased at a rate of 0.05 logit points, which corresponds to a 5 percent increase in the odds-ratio, per year. Thus age-differentials have clearly widened over the observational period. Regarding the educational level, the results reveal that almost all educational groups experienced an increasing risk of holding a temporary contract. This particularly holds for the elementary level as well as the level of intermediate/full secondary education with vocational train- ing. On the one hand, these results suggest that there has been a convergence in education-related temporary employment differentials. On the other hand, this convergence implies a worsening of the labour market position of workers holding degrees below the tertiary level. Finally, with respect to the impact of occupational class on the risk of holding a temporary contract, the results indicate no change in the effect of occupational class over time. This implies 
that the increase in class-specific proportions of temporary employment found in the descriptive analysis above is solely due to the composition of these classes with respect to workers' individual and job-related characteristics.

\section{Conclusion}

Previous research on temporary employment relationships has revealed that this type of employment is related to serious socio-economic disadvantages - lower wages and higher unemployment risks of workers holding temporary contracts being only two examples of these disadvantages. At the same time, these labour market positions are not equally distributed across the work force, since characteristics like age, education, and occupational class have been shown to be important determinants for an individual's probability of holding a temporary contract rather than a permanent one. Whereas these allocation patterns are well documented by empirical studies, little research has been done on the question of whether and to what extent these patterns have changed over time. However, given the substantial structural and institutional changes that have affected the German labour market over the last two decades, there are reasons to believe that risk patterns related to temporary jobs, and thus the contours of social inequality itself, have changed.

On the basis of data from the German Mikrozensus for the years 1989-2005, our empirical results indicate that there have indeed been changes both in the overall incidence of temporary contracts and in the specific risk faced by certain labour market groups of holding such a contract. On the aggregate level there has been only a modest increase in the overall proportion of temporary employment in the West German labour market over the last 20 years, which is an interesting result given the significant relaxation of regulations controlling the use of temporary employment during this period. Obviously, the demand for this type of employment relation and thus the demand for greater external flexibility seems to be lower than some commentators have thought, referring to the level of employment protection as one of the main structural problems of the German labour market (Siebert 1997).

However, while the overall proportion of temporary jobs has increased only slightly, for certain social groups relative to other labour market groups there have been clear shifts in the risk of holding a temporary contract. In particular, the results indicate that young people, as labour market outsiders, faced an increasing risk of temporary employment. In the observational period, the proportion of young people aged 16-25 holding a temporary contract almost doubled, reaching about 25 percent in 2005. This result holds even after controlling for other individual and job characteristics. Thus, inequality in the distribution of temporary employment seems to have deepened substantially across the age dimension. This is in line with the predictions of Mills and Blossfeld (2005) who argue that young people, as labour market outsiders, are especially affected by increasing market uncertainties.

In addition to the strengthening inequality across age groups, the results reveal changes in the education-related inequality patterns. Especially those with elementary education (without and with vocational training) and those with intermediate/full secondary education with vocational training faced an increasing risk of holding a temporary job and lost much of their relative advantage when compared to people with university education. This confirms the general predictions of Breen (1997) and DiPrete et al. (2006) who argue that European labour markets have absorbed market uncertainties by allocating an increasingly large proportion of low-educated workers to flexible jobs.

Overall, the empirical analysis revealed that, in particular, individuals who belong to groups already in a weak labour market position, namely the young and the low-educated, were increasingly allocated to inferior employment relations. In addition, while the impact of these "classical" determinants shaped social inequality in the described way, there are no signs of a growing importance of other (typically unobserved) characteristics that determine an individual's risk of holding a temporary contract (such as ability or motivation). Thus, these findings provide evidence of a strengthening of social inequality along the existing lines of social division and refute Beck's $(1992,2000)$ notion of an inequality that is less and less socially structured.

Though the empirical analysis did not allow us to disentangle the effects of structural and institutional changes in detail, the findings seem to suggest that partial labour market reforms - such as lowering restrictions on the use of temporary employment while leaving the level of protection of standard employment relations unchanged - clearly involve the risk of reinforcing social inequality. The recent examples of France and Spain, where the relaxation of regulations controlling the use of temporary employment led to an intensification of labour market segmentation (Blanchard and Landier 2002; Polavieja 2006), might underscore this argument. However, as the present analysis is confined to the case of temporary employment, further research is required in order to determine to what extent our conclusion applies to other forms of flexible employment relationships.

\section{Executive summary}

While previous research on temporary employment has shown that certain labour market groups are more likely 
than others to enter this kind of employment, there has been scant research on the question concerning to what extent these allocation patterns have changed over time. Against the background of pervasive structural and institutional changes which have affected the West German labour market since the beginning of the 1990s, there are reasons to believe that allocation patterns have changed as well. In this paper, we focus the discussion on the effects of education, age and occupational class as these characteristics are not only important determinants of temporary jobs but also constitute core elements of social stratification and inequality.

On a theoretical level there are different views regarding the quality of these changes. On the one hand, as argued by some scholars, labour market risks are expected to have become less and less socially structured. In this perspective, existing determinants of social stratification like education and occupational class will lose their importance for social inequality as new risks unrelated to these "classical" determinants emerge. On the other hand and in sharp contrast to the assumption of a growing individualisation of inequality, some authors argue that social inequality has been exacerbated along the existing lines of social division. Thus, traditional social inequality patterns, such as those based on educational resources and occupational class, are expected to persist or even increase.

To evaluate this question empirically, we use data from the German Mikrozensus for the period from 1989 to 2005. The analysis reveals first of all that, on the aggregate level, the overall proportion of temporary employment has increased only slightly during that period. This is an interesting result given the significant relaxation of regulations controlling the use of temporary employment during this period. Obviously, the demand for this type of employment relation and thus the demand for greater external flexibility seem to be lower than some commentators have thought.

Second, for certain social groups there have been clear shifts in the risk of holding a temporary contract. In particular, the results indicate that young people, as labour market outsiders, faced an increasing risk of temporary employment. In the observational period, the proportion of young people aged 16-25 holding a temporary contract almost doubled, reaching about 25 percent in 2005 . In addition to the strengthening inequality across age groups, the results reveal changes in the education-related inequality patterns. Especially those with elementary education and those with intermediate/full secondary education with vocational training faced an increasing risk of holding a temporary job and lost much of their relative advantage when compared to people with university education. Overall, the empirical analysis revealed that, in particular, individuals who belong to groups already in a weak labour market position, namely the young and the low-educated, were increasingly allocated to inferior employment relations.

Third, while the impact of these "classical" determinants shaped social inequality in the described way, there are no signs of a growing importance of other (typically unobserved) characteristics that determine an individual's risk of holding a temporary contract (such as ability or motivation). Thus, these findings provide evidence of a strengthening of social inequality along the existing lines of social division and refute the notion of an inequality that is less and less socially structured.

\section{Kurzfassung}

Obwohl viele Studien zur befristeten Beschäftigung zeigen können, dass bestimmte Arbeitsmarktgruppen eine erhöhte Wahrscheinlichkeit aufweisen, in befristeten Arbeitsverhältnissen beschäftigt $\mathrm{zu}$ sein, existieren bisher nur sehr wenige Forschungsergebnisse hinsichtlich der Frage, ob und inwieweit sich diese Allokationsmuster über die Zeit verändert haben. Angesichts tiefgreifender struktureller und institutioneller Veränderungen, die sich seit Anfang der 1990er-Jahre auf den westdeutschen Arbeitsmarkt auswirken, liegt jedoch die Vermutung nahe, dass die Besetzungsmuster von befristeter Beschäftigung ebenfalls einem Wandel unterlagen. In diesem Beitrag liegt das Hauptaugenmerk auf den Effekten der Bildung, des Alters und der beruflichen Klassenposition. Diese Merkmale sind nicht nur wichtige Determinanten für befristete Beschäftigungsverhältnisse, sondern stellen wesentliche Elemente sozialer Stratifizierung und Ungleichheit dar.

Auf der theoretischen Ebene existieren allerdings unterschiedliche Einschätzungen bezüglich der Art eines solchen Wandels der Allokationsmuster. So erwarten einige Beobachter, dass Risiken immer weniger sozial strukturiert sein werden. In dieser Perspektive verringert sich der Einfluss bisher bestehender Determinanten sozialer Stratifikation, wie etwa der der Bildung oder der beruflichen Klassenposition, während neue Risiken, die jenseits dieser „klassischen“ Determinanten wirken, an Bedeutung für soziale Ungleichheit gewinnen. Entgegen dieser Annahme einer zunehmenden Individualisierung von sozialer Ungleichheit betonen andere Autoren, dass sich Ungleichheiten auf dem Arbeitsmarkt insbesondere entlang bereits bestehender sozialer Spaltungslinien verstärken. Demzufolge wäre zu erwarten, dass sich alters-, bildungsund klassenspezifische Ungleichheitsmuster als weitgehend stabil erweisen oder im Zeitverlauf sogar weiter verfestigen.

Um diese Frage empirisch zu überprüfen, nutzen wir Daten des Mikrozensus für die Jahre 1989 bis 2005. Die Analysen zeigen dabei erstens, dass der Anteil befristeter Beschäftigungsverhältnisse über diesen Zeitraum insgesamt 
nur leicht angestiegen ist. Vor dem Hintergrund, dass die gesetzlichen Regelungen des Einsatzes von befristeter Beschäftigung in diesem Zeitraum signifikant gelockert wurden, ist dies ein interessantes Ergebnis. Offenbar fällt die Nachfrage nach diesem Beschäftigungstyp und damit der Bedarf an externer Flexibilität geringer aus, als von einigen Beobachtern behauptet.

Zweitens wird deutlich, dass das Risiko, in einem befristeten anstatt in einem unbefristeten Arbeitsverhältnis beschäftigt zu sein, für bestimmte Gruppen über die Zeit zugenommen hat. Dies trifft insbesondere für junge Arbeitnehmerinnen und Arbeitnehmer zu: Für die Gruppe der 16-25-Jährigen verdoppelte sich der Anteil der befristetet Beschäftigten im Beobachtungszeitraum auf 25 Prozent im Jahre 2005. Zusätzlich zu dem Wandel der altersbezogenen Ungleichheitsstrukturen lassen sich auch Änderungen in den bildungsspezifischen Risikomustern finden. Vor allem diejenigen Personen mit niedrigem und mittlerem Bildungsniveau verzeichneten ein steigendes Befristungsrisiko, sodass sie ihre relativen Vorteile im Vergleich zu Personen mit Hochschulabschlüssen größtenteils einbüßten. Insgesamt zeigen die Ergebnisse damit, dass insbesondere solche Gruppen zunehmend in befristeten Arbeitsverhältnissen zu finden sind, die ohnehin eine relativ schwache Position am Arbeitsmarkt aufweisen.

Drittens lassen die Ergebnisse nicht erkennen, dass solche Merkmale, die typischerweise unbeobachtet sind (wie etwa Fähigkeiten oder Motivation), für den Besetzungsprozess befristeter Beschäftigungsverhältnisse an Bedeutung gewonnen haben. Unsere Befunde legen entgegen der These einer Entstrukturierung sozialer Ungleichheit vielmehr den Schluss nahe, dass sich soziale Ungleichheit entlang bereits bestehender Spannungslinien verschärft hat.

\section{Appendix}

Changes in the Regulation of the Use of Temporary Contracts in Germany 1985-2005

1985: Before 1985, fixed-term contracts were restricted to a maximum duration of 6 months, and only for specific reasons such as probationary period, special task completions, seasonal fluctuations, temporarily high volumes of work, deputisation, on the-job-training and public employment measures. The main law regulating temporary employment was the "Beschäftigungsförderungsgesetz"(Law for the Improvement of Employment Opportunities) of January 1985. Contract limitations up to 18 months were granted without specific reasons in certain cases, such as for a newly hired employee or successful apprentices wishing to continue their employment if a permanent position wasn't available. Contracts up to 24 months were permitted without specific reasons in businesses with fewer than 20 employees, providing there was no objective connection to a previous contract within four months. A follow-up fixed-term contract was allowed subject to specific reasons.

1996: The second improvement to the Employment Opportunities Act of 1996 extended the opportunities for using fixed-term contracts. The restrictions applied to newly hired employees and successful apprentices were removed. The maximum duration of a fixed-term contract was increased to 24 months, and within this period it could be renewed three times. The maximum duration for a fixed-term contract for employees over 60 became unlimited. However, it was forbidden to sign a fixed-term contract after previous fixed-term or permanent employment with the same employer within four months. Nevertheless, it became possible to add a fixed-term contract without specific reasons to a fixed-term employment with specific reasons.

2001: In January 2001, Germany enacted a new law, the "Teilzeit- und Befristungsgesetz" (Law of part-time and fixed-term employment relationship), which abolished the former Law for the Improvement of Employment Opportunities. The maximum duration of a fixed-term contract remained 24 months, and within this period it can be renewed three times. However, follow-up fixed-term contracts were forbidden if there was an earlier fixed-term employment contract between the employer and employee, regardless of the elapsed time. The age limit for older employees without limitations regarding the contract duration was reduced to 58. Anti-discrimination regulations guaranteed equal employment rights for fixed-term employees and open-ended employees with otherwise similar characteristics.

2003: Germany enforced some new regulations with the "Erstes Gesetz für moderne Dienstleistungen am Arbeitsmarkt" policy in 2003, which allowed unlimited fixed-term contracts for employees over the age of 52 . This rule does not apply if there was a previous fixed-term employment with the same employer within six months. The 2003 policy "Gesetz zu Reformen am Arbeitsmarkt" allowed new businesses to sign fixed-term contracts without specific reasons for a maximum duration of four years.

\section{References}

Acemoglu, D.: Technical change, inequality, and the labor market. J. Econ. Lit. 40, 7-72 (2002)

Allison, P.D.: Comparing logit and probit coefficients across groups. Sociol. Methods Res. 28(2), 186-208 (1999)

Alvarez, R.M., Brehm, J.: American ambivalence towards abortion policy - development of a heteroskedastic probit model of competing values. Am. J. Political Sci. 39(4), 1055-1082 (1995)

Amuedo-Dorantes, C.: Work transitions into and out of involuntary temporary employment in a segmented market: evidences from Spain. Ind. Labor Relat. Rev. 53(2), 309-325 (2000) 
Beck, U.: Risk society: towards a new modernity. Sage, New Delhi (1992)

Beck, U.: The brave new world of work. Polity Press, Cambridge (2000)

Bentolila, S., Bertola, G.: Firing costs and labour demand: how bad is eurosclerosis? Rev. Econ. Stud. 57(3), 381-402 (1990)

Blanchard, O., Landier, A.: The perverse effects of partial labour market reform: fixed-term contracts in France. Econ. J. 112, 214-244 (2002)

Blanchard, O., Wolfers, J.: The role of shocks and institutions in the rise of European unemployment: the aggregate evidence. Econ. J. 110(462), 1-33 (2000)

Blau, F.D., Kahn, L.M.: At home and abroad: U.S. labor market performance in international perspective. Russell Sage Foundation, New York (2002)

Boockmann, B., Hagen, T.: Befristete und andere ,atypische“ Beschäftigungsverhältnisse: Wird der Arbeitsmarkt funktionsfähiger? Z. Arbeitsmarktforsch. 38(2-3), 305-324 (2005)

Boockmann, B., Hagen, T.: Befristete Beschäftigungsverhältnisse - Brücken in den Arbeitsmarkt oder Instrumente der Segmentierung? Nomos, Baden-Baden (2006)

Booth, A.L., Francesconi, M., Frank, J.: Temporary jobs: stepping stones or dead ends? Econ. J. 112(480), 189-213 (2002)

Breen, R.: Risk, recommodification and stratification. Sociology 31(3), 473-489 (1997)

Buchholz, S., Kurz, K.: Increasing employment instability among young people? Labor market entries and early careers in Germany since the mid-1980s. FlexCareer Working Paper No. 3. University of Bamberg, Bamberg (2005)

Cahuc, P., Postel-Vinay, F.: Temporary jobs, employment protection and labor market performance. Labour Econ. 9(1), 63-91 (2002)

DiPrete, T.A., Goux, D., Maurin, E., Quesnel-Vallee, A.: Work and pay in flexible and regulated labor markets: a generalized perspective on institutional evolution and inequality trends in Europe and the U.S. Res. Soc. Stratif. Mobil. 24(3), 311-332 (2006)

Ebbinghaus, B., Visser, J.: Trade unions in Western Europe since 1945. Palgrave Macmillan, London (2000)

Erikson, R., Goldthorpe, J.H.: The constant flux: a study of class mobility in industrial societies. Clarendon Press, Oxford (1992)

Esping-Andersen, G.: The three worlds of welfare capitalism. Princeton University, Princeton Press (1990)

Esping-Andersen, G., Regini, M.: Why deregulate labour markets? Oxford University Press, Oxford (2000)

Ganzeboom, H.B.G., Treiman, D.J.: Three internationally standardised measures for comparative research on occupational status. In: Hoffmeyer-Zlotnik, J.H.P., Wolf, C. (eds.) Advances in cross-national comparison. A European working book for demographic and socio-economic variables, pp. 159-193. Kluwer Academic/Plenum Publishers, New York (2003)

Giesecke, J.: Arbeitsmarktflexibilisierung und Soziale Ungleichheit Sozioökonomische Konsequenzen befristeter Beschäftigungsverhältnisse in Deutschland und Großbritannien. VS Verlag für Sozialwissenschaften, Wiesbaden (2006)

Giesecke, J., Groß, M.: Temporary employment: chance or risk? Europ. Sociol. Rev. 19(2), 161-177 (2003)

Goldthorpe, J.H.: The Service Class Revisited. In: Butler, T., Savage, M. (eds.) Social Change and the Middle Class, pp. 313-329. UCL Press, London (1995)

Goldthorpe, J.H.: Social class and the differentiation of employment contracts. In: Goldthorpe, J.H. (ed.) On sociology. Numbers, narratives, and the integration of research and theory, pp. 206-223. Oxford University Press, Oxford (2000)

Goldthorpe, J.H.: Globalisation and Social Class. West Europ. Pol. 25(3), 1-28 (2002)
Groß, M.: Die Folgen prekärer Arbeitsverhältnisse für das Ausmaß sozialer Ungleichheit: Einkommensbenachteiligung befristeter Arbeitsverträge. In: Lüttinger, P. (Hrsg.) Sozialstrukturanalysen mit dem Mikrozensus. Zentrum für Umfragen, Methoden und Analysen, Mannheim (1999)

Hagen, T.: Do temporary workers receive risk premiums? Assessing the wage effects of fixed-term contracts in West Germany by a matching estimator compared with parametric approaches. Labour Rev. Labour Econ. Ind. Relat. 16(4), 667-705 (2002)

Hagen, T.: Does Fixed-term Contract Employment Raise Firms' Adjustment Speed? Evidence from an Establishment Panel for West Germany. Jahrb. Nationalökonomik Stat. 223(4), 403-421 (2003)

Hagen, T.: Labour market effects of fixed-term employment contracts - microeconometric analysis for West Germany. Hochschulschrift, Frankfurt am Main (2004)

Kalleberg, A.L.: Nonstandard employment relations; part-time, temporary and contract work. Ann. Rev. Sociol. 26, 341-365 (2000)

Keele, L., Park, D.K.: Difficult choices: an evaluation of heterogeneous choice models. 2006 Annual Meeting of the American Political Science Association, Philadelphia (2006)

Lechert, Y., Schroedter, J., Lüttinger, P.: Die Umsetzung der Bildungsklassifikation CASMIN für die Volkszählung 1970, die Mikrozensus-Zusatzerhebung 1971 und die Mikrozensen 1976-2004. ZUMA-Methodenbericht Nr. 2006/12. Centre for Survey Research and Methodology, Mannheim (2006)

Lindbeck, A., Snower, D.J.: The insider-outsider theory: a survey. IZA Discussion Paper No. 534. Institute for the Study of Labor, Cologne (2002)

Long, J.S.: Regression models for categorical and limited dependent variables. Sage Publications, Thousand Oaks (1997)

Long, J.S., Freese, J.: Regression models for categorical dependent variables using Stata. Stata Press, College Station, Texas (2006)

McGinnity, F., Mertens, A., Gundert, S.: A Bad Start? Fixed-Term Contracts and the Transition from Education to Work in West Germany. Europ. Sociol. Rev. 21(4), 359-374 (2005)

Mertens, A., Gash, V., McGinnity, F.: The cost of flexibility at the margin. Comparing the wage penalty for fixed-term contracts in Germany and Spain using quantile regression. Labour Rev. Labour Econ. Ind. Relat. 21(4-5), 637-666 (2007)

Mertens, A., McGinnity, F.: Wages and Wage Growth of Fixed-Term Workers in East and West Germany. Appl. Econ. Q. 50(2), 139-163 (2004)

Mills, M., Blossfeld, H.-P.: Globalization, uncertainty and changes in early life courses. Z. Erziehungswiss. 6(2), 188-218 (2005)

Müller, W., Shavit, Y.: The institutional embeddedness of the stratification process: a comparative study of qualifications and occupations in thirteen countries. In: Shavit, Y., Müller, W. (eds.) From school to work. A comparative study of educational qualifications and occupational destinations, pp. 1-48. Oxford University Press, Oxford (1998)

Müller, W., Wolbers, M.H.J.: Educational attainment in the European Union. Recent trends in qualification patterns. In: W. Müller, M. Gangl (eds.) Transitions from education to work in Europe. The integration of youth into EU labour markets, pp. 23-62. Oxford University Press, Oxford (2003)

OECD: Employment Outlook. OECD, Paris (2004)

Polavieja, J.G.: The incidence of temporary employment in advanced economies: why is Spain different? Europ. Sociol. Rev. 22(1), 61-78 (2006)

Rudolph, H.: Befristete Arbeitsverträge sind bald neu zu regeln. IAB Kurzbericht No. 12. Institut für Arbeitsmarkt- und Berufsforschung, Nürnberg (2000) 
Schömann, K., Rogowski, R., Kruppe, T.: Labour Market Efficiency in the European Union. Employment Protection and Fixed-Term Contracts. Routledge, London (1998)

Siebert, H.: Labor market rigidities: at the root of unemployment in Europe. J. Econ. Perspect. 11(3), 37-54 (1997)

Williams, R.: Using heterogeneous choice models to compare logit and probit coefficients across groups. Working Paper. University of Notre Dame, Notre Dame (2007)

Wooldridge, J.M.: Econometric analysis of cross section and panel data. MIT Press, Cambridge, MA (2002)
Michael Gebel, studies in social sciences and economics at the University of Mannheim and the University of Louvain-la-Neuve, 2005 Diploma in Economics, 2006 Diploma in Social Sciences and Master of Arts in Economics. Since 2006 researcher at the Mannheim Centre for European Social Research (MZES), University of Mannheim.

Research interests: school-to-work transition, atypical employment, and international comparative social research.

e-mail: michael.gebel@mzes.uni-mannheim.de

Johannes Giesecke, studies of Social Sciences at Humboldt-University Berlin, Graduation 2000. 2000-2007 junior researcher at Humboldt-University Berlin and University Mannheim. 2005 Doctorate Dr. phil. Since 2007 senior researcher at the Social Science Research Center Berlin (WZB).

Research interests: Labour market flexibility, wage inequality, quantitative methods.

e-mail: johannes.giesecke@wzb.eu 